\title{
Misogyny: Are Personal Laws Androcentric?
}

\section{Pearl Monteiro'}

\begin{abstract}
The age-old prejudice of misogyny is still retained in insidious form even in legislations. There are numerous international conventions, as well as Constitutional provisions which claim to set man and woman on an equal plane. In India, one legislative sphere which prima facie appears to perpetuate the gender divide are the personal laws. In India, except for the State of Goa, personal matters are determined on the basis of religion. Different religions follow different laws, but what is common to them all, is the secondary position accorded to women. This paper discusses the international provisions dealing with equal human rights such as, Charter of the United Nations, 1945, The Universal Declaration of Human Rights, 1948, International

Covenant on Economic, Social and Cultural Rights, 1966 and The Convention on the Elimination of All Forms of Discrimination against Women. The paper elaborates on the Constitutional provisions providing for equality as well investigates whether the personal law provisions applicable to the Hindu, Muslim, and Christian women dealing with marriage, divorce, guardianship, and inheritance are discriminatory and misogynistic in nature. The paper studies the laws from date of enactment till the present day. The method of study is doctrinal. As a road map or suggestion, the analogous provisions of the Uniform Civil Code in Goa are highlighted. Judicial precedents are cited, suggestions are put forward.
\end{abstract} Covenant on Civil and Political Rights, 1966, International

Key Words - Human Rights, Gender Justice, Fundamental Rights, Misogyny, Personal Laws

\footnotetext{
1 Assistant Professor, V.M Salgaocar College of Law, Goa, India
} 


\section{"Achieving gender equality requires the engagement of women and men, girls and boys. It is everyone's responsibility." - Ban Ki-moon ${ }^{2}$}

\section{Introduction}

Alternately revered, loved, worshiped, hated, witch hunted, burnt and raped, throughout history, the life of a woman, has been fraught with dichotomy, and danger. A telling example is the life of Joan of $\mathrm{Arc}^{3}$, she led the French army to victory, but was taken as a witch and burnt at the stake for her trouble. The ancient Greeks called her, "the beautiful evil," at the same time Plato in The Republic, advocated that woman receive the same education as men. In India, in the Vedic era, women led an emancipated life, she was educated and equal to men. Special mention may be made of Maitree and Gargi ${ }^{4}$. But at the same time she has been told by the highest authority that being subservient to her husband is the greatest good. ${ }^{5}$

Misogyny is the world's oldest prejudice. ${ }^{6}$ It signifies feelings of hating women, or the belief that men are much better than women. Androcentric is defined as, dominated by or emphasizing masculine interests or a masculine point of view. ${ }^{8}$ Androcentrism is emphasized by religious texts that led to the belief that God created man first, that this man was created in the image and likeness of God. That the man had to sacrifice a rib for the creation of woman, that woman was created out of man. That woman was created to be a companion for man, purpose of woman's existence was to fulfill man's desires. That the downfall of man was due to woman, that he had to leave the Garden of Eden due to her. ${ }^{9}$ In all probability these premises led to the treating of women as chattel ${ }^{10}$ in all systems of law.

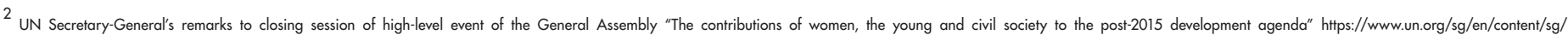
statement/2014-03-07/secretary-generals-remarks-closing-session-high-level-event-general (September 20, 2021).

3 Kathryn Harrison, Joan of Arc: A Life Transfigured (Reprint edition, Anchor 2015).

4 Subhamoy Das, "Famous Female Figures of Vedic India." Learn Religions, Feb. 11, 2020, learnreligions.com/famous-female-figures-of-vedic-india-1770399 (March 3, 2021).

5 Sreyashi Ghosh, "Intersectional Feminism - Desi Style" Saturday, May 2, 2020 https://feminisminindia.com/2018/01/11/manusmriti-ultimate-guide-good-woman/ (March 3, 2021)

6 Holland J., Misogyny the World's Oldest Prejudice (Robinson London, 2006)

7 Cambridge Dictionary https://dictionary.cambridge.org/dictionary/english/misogyny (March 3, 2021)

${ }^{8}$ Merriam Webster Dictionary merriam-webster.com/dictionary/androcentric (March 3, 2021)

9 See Bible NIV: Genesis 1

10 Joseph Shine v. Union of India 2018 SC 1676
} 


\section{Literature Review}

Traces of misogyny are visible in the teachings of the Greek philosophers, prominently Aristotle and Plato.." Christian doctrine has been interpreted and given rise to misogyny. ${ }^{12}$ Patriarchy and misogyny have permeated society since ancient times. ${ }^{13}$ Classical teachings eschew association with women as instrumental to progress. ${ }^{14}$ The media insidiously promotes intolerance and violence towards women. ${ }^{15}$ Domestic violence is a concrete manifestation of misogynic culture. ${ }^{16}$ Today, regrettably the world is also facing a digital culture of misogyny. ${ }^{17}$ A perusal of the various laws purporting to be pro woman raises presumptions of misogynistic undercurrents. ${ }^{18}$ Open and indiscriminate harassment of women on social media platforms perpetuates the problem ${ }^{19}$ Deep rooted prejudices deter reforms. ${ }^{20}$ In India, it is most unfortunate to observe misogyny in all strata and sections of society. ${ }^{21}$ The multifarious manifestos of the United Nations have made it abundantly clear that world peace can only be achieved if women are emancipated. ${ }^{22}$ The entire literature review bears testament to the presence of misogyny and the need to eliminate the same for true progress of society, however the status quo is maintained.

\section{Current Trends}

Theory and practice unite to show education as a reliable tool to overset generations of misogynistic teachings. ${ }^{23}$ Contemporary views advocate a strong literary critique to promote equality. ${ }^{24}$ The role of language in reform is also predominant in bringing about change in mindset. ${ }^{25}$ Several countries have successfully demonstrated law as an important instrument in binging reform to women. ${ }^{26}$

11

11 Christia Mercer, "The Philosophical Roots of Western Misogyny", Philosophical Topics 46, no. 2 (2018): 183-208. Accessed June 9, 2021. https://www.jstor.org/stable/26927955.

12 Rosemary Radford Ruether "Sexism and Misogyny in the Christian Tradition: Liberating Alternatives." Buddhist-Christian Studies 34 (2014): 83-94. Accessed June 9, 2021. http://www.jstor.org/stable/24801355.

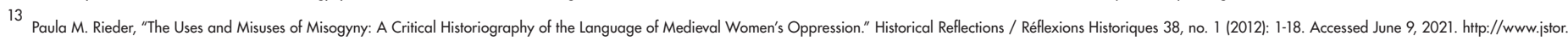
org/stable/23267757.

14 Jefferds Huyck, "Another Sort Of Misogyny: Aeneid 9.141-142" Harvard Studies in Classical Philology 108 (2015): 245-63. Accessed June 9, 2021. http://www.jstor.org/stable/44157815.

15 Denise Buiten, "Silences Stifling Transformation: Misogyny and Gender-Based Violence in the Media", Agenda: Empowering Women for Gender Equity, no. 71 (2007): 114-21. Accessed June 9, 2021. http://www.jstor.org/stable/27739254.

16 Jonathan Herring, "The Severity Of Domestic Abuse", National Law School of India Review 30, no. 1 (2018): 37-50. Accessed June 9, 2021. https://www.jstor.org/stable/26743931.

17 Angela Nagle, "The New Man of 4chan", The Baffler, no. 30 (2016): 64-76. Accessed June 9, 2021. http://www.jstor.org/stable/43959201.

18

18 Marge Berer, "Abortion Law and Policy Around the World: In Search of Decriminalization." Health and Human Rights 19, no. 1 (2017): 13-27. Accessed June 9, 2021.

19 Kim Barker, and Olga Jurasz "Online Misogyny: A Challenge For Digital Feminism?" Journal of International Affairs 72, no. 2 (2019): 95-114. Accessed June 9, 2021. https://www.jstor.org/stable/26760834.

20 Lena-Maria Möller, "An Enduring Relic: Family Law Reform and the Inflexibility of Wil|lya." The American Journal of Comparative Law 63, no. 4 (2015): 893-925. Accessed June 9, 2021. https://www.jstor.org/stable/26425444.

${ }^{21}$ Chapman, Jean, "Violence against Women in Democratic India: Let's Talk Misogyny." Social Scientist 42, no. 9/10 (2014): 49-61. Accessed June 9, 2021. http://www.jstor.org/stable/24372976.

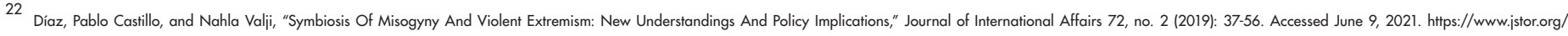
stable/26760831.

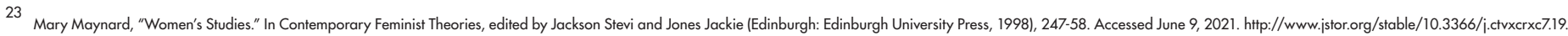

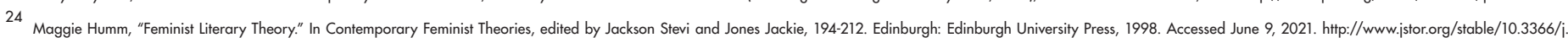
ctvxcrxc7.16. 


\section{International Provisions}

Over the decades, many international provisions have dealt with the concepts of human rights for all without discrimination, leading to gender justice. The very concept of human rights, refer to rights applicable to all human beings without discrimination, simply, by virtue of their being human. These rights, by definition, are inherent, universal and inalienable. Some international provisions may be found in the Charter of the UN, which affirms the commitment of the UN to equality of the genders. ${ }^{27}$ Provisions in the Universal Declaration of Human Rights, ${ }^{28}$ International Covenant on Civil and Political Rights ${ }^{29}$ and the International Covenant on Economic, Social and Cultural Rights ${ }^{30}$ reiterate the same

The Convention on the Elimination of All Forms of Discrimination against Women (CEDAW), is often described as an international bill of rights for women. Consisting of a preamble and 30 articles, it defines what constitutes discrimination against women and sets up an agenda for national action to end such discrimination. ${ }^{31}$ It recognizes, "...the full and complete development of a country, the welfare of the world and the cause of peace require the maximum participation of women on equal terms with men in all fields" Binding legal obligation to legislate a unform civil code rests on parties to CEDAW. ${ }^{33}$

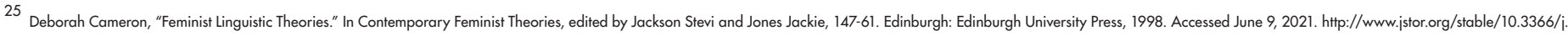
ctvxcrxc7.13.

26

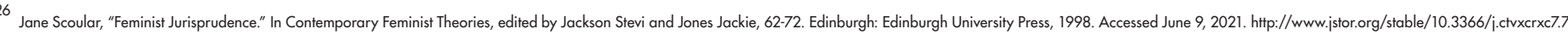

27 Charter of the United Nations, 1945

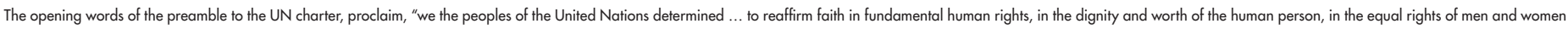
and of nations large and small...." Preamble https://www.un.org/en/sections/un-charter/preamble/(March 3, 2021)

28 The Universal Declaration of Human Rights, 1948

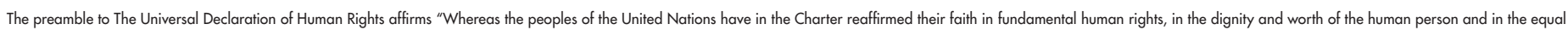
rights of men and women ...." Universal Declaration of Human Rights https://www.un.org/en/universal-declaration-human-rights/(March 3, 2021) Emphasis supplied

29 The Covenant expects, that the States Parties to the present Covenant undertake to ensure the equal right of men and women to the enjoyment of all civil and political rights set forth in the present Covenant.

30 This Covenant enjoins upon the States Parties to the present Covenant undertake to ensure the equal right of men and women to the enjoyment of all economic, social and cultural rights set forth in the present Covenant.

31 ibid
} 


\section{Constitutional Position}

The Constitution of India, has the distinction of being a secular one, but this has not resulted in a secular society. ${ }^{34}$ Dr Ambedkar, founding father of the Constitution, deliberated on the nature of the Constitution as being individualistic, rather than group centered, thus encouraging diversity. ${ }^{35}$ Respect for minorities and honoring their diversity is in the ethos of our Constitution. ${ }^{36}$ The Constitution, provides for equality for all persons ${ }^{37}$. In addition to the general provision of equality, the Constitution makers felt it necessary to expressly prohibit discrimination on the ground of sex. ${ }^{38}$ Moreover, they were impelled to provide special provisions for women. ${ }^{39}$ The tendency of the law has been, to patronize women as evident from several judgments of the honorable courts. ${ }^{40}$

\section{Personal laws}

The colorful mosaic that is India, is varied not only in language, food, dress, and every conceivable notion known to man, but also in religion. This variety is rich and remarkable; however, history has depicted that in spite of "university in diversity" there are instances where perhaps, a "uniformity in diversity" is called for.

In personal matters such as marriage, divorce, guardianship, inheritance and the like, except for the miniscule State of Goa, the vast majority of India is governed by personal laws which are applicable on the basis of religion. Not only do these laws vary from person to person based on religion, but also within a religion, the law often discriminates between gender. Group specific laws are also more resistant to change. ${ }^{41}$

Here a limited reference is made to the binary discrimination between male and female. However, not only should the relevant laws be amended to provide for equality between the male and female stereotypes, but also adequate provision be made for the third gender, who sadly, only found mention in the

\footnotetext{
32 The Convention on the Elimination of All Forms of Discrimination against Women (CEDAW) https://www.un.org/womenwatch/daw/cedaw/text/econvention.htm (emphasis supplied)(March 3, 2021)

33 Jyoti Rattan, "Uniform Civil Code In India: A Binding Obligation Under International And Domestic Law." Journal of the Indian Law Institute 46, no. 4 (2004): 577-87. Accessed June 10, 2021. hittp://www.jstor.org/stable/43951938.

34 Tarkunde, V.M. "Secularism and the Indian Constitution." India International Centre Quarterly 22, no. 1 (1995): 143-52. Accessed June 10, 2021. http://www.jstor.org/stable/23003717

35 Dhavan, Rajeev. "Religious Freedom in India." The American Journal of Comparative Law 35, no. 1 (1987): 209-54. Accessed June 10, 2021. doi:10.2307/840167.

36 Philips, Amali. "Sharia and Shah Bano: Multiculturalism and Women's Rights." Anthropologica 53, no. 2 (2011): 275-90. Accessed June 10, 2021. http://www.jstor.org/stable/41473879.

37 Art 14. Equality before law The State shall not deny to any person equality before the law or the equal protection of the laws within the territory of India

38 Art 15. Prohibition of discrimination on grounds of religion, race, caste, sex or place of birth

(1) The State shall not discriminate against any citizen on grounds only of religion, race, caste, sex, place of birth or any of them

39 Art 15 (3) Nothing in this article shall prevent the State from making any special provision for women and children

40 In Raghubans Saudagar Singh v. The State of Punjab AIR 1972 P \& H 117 The Learned High Court declined to allow women to work in men's jails, asserting that a task which was difficult for men, would be impossible for women.

${ }^{41}$ Narendra Subramanian, "Legal Change and Gender Inequality: Changes in Muslim Family Law in India." Law \& Social Inquiry 33, no. 3 (2008): 631-72. Accessed June 10, 2021. http://www.jstor.org/stable/20108777.
} 
Indian Penal Code, $1860{ }^{42}$ but never in the personal laws. ${ }^{43}$ Hindus, Muslims and Christians have different laws governing marriage, divorce, guardianship, inheritance and other personal matters. Colonial practice led to loss of some of the few rights enjoyed by women under customary Hindu law. ${ }^{44}$ Post-independence, the earliest laws to be legislated, touched upon the personal matters of the Hindu. ${ }^{45}$ Several legislations were enacted in quick succession. The Hindu Adoptions and Maintenance Act, discriminates between male and female, both, in giving and taking in adoption. Although the Act requires that the male take consent of his wife before taking in adoption, it is observed that the male has the prerogative whether to adopt or not. ${ }^{46}$ A female Hindu, on the other hand, may only adopt, if unmarried, or divorced, or whose husband has been declared to be legally incompetent. ${ }^{47}$ Akin is the case of giving in adoption, where the father and not the mother has prerogative. ${ }^{48}$ Similarly, an illustrative case is that of guardian ship which arose before Supreme Court in Ms. Githa Hariharan v. Reserve Bank of India ${ }^{49}$ The Case concerned the application of S. $6^{50}$ of The Hindu Minority and Guardianship Act, 1956, wherein the mother is designated as natural guardian after the father. ${ }^{51}$ In this case, father and mother and minor agreed that mother of minor would act as guardian for investments made in minor's name, however, the Bank directed the production of application form signed by father of minor or certificate of guardianship in favor of mother.

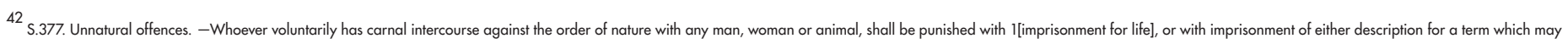

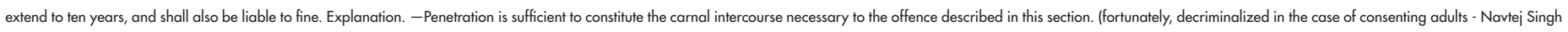
Johar v Union of India AIR 2018 SC 4321)

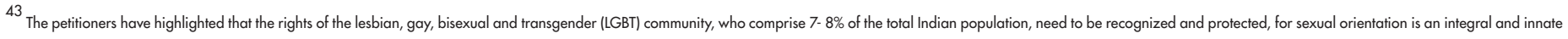
facet of every individual 's identity. Navtej Singh Johar v Union of India AIR 2018 SC 4321

${ }^{44}$ Amrita Shodhan, "Women, Personal Laws and the Changing Juridical Practice." Economic and Political Weekly 35, no. 15 (2000): 1259-261. Accessed June 10, 2021. http://www.jstor.org/stable/4409145.

45 J. Duncan M. Derrett. "Statutory Amendments of the Personal Law of Hindus Since Indian Independence." The American Journal of Comparative Law 7, no. 3 (1958): $380-93$. Accessed June 10, 2021. doi:10.2307/837671.

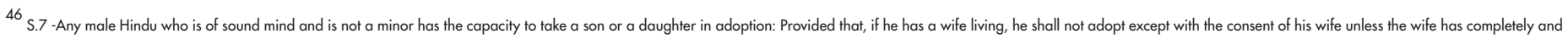

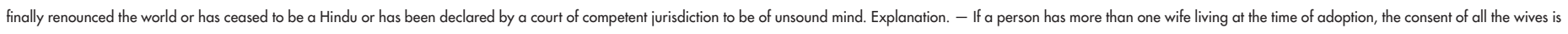
necessary unless the consent of any one of them is unnecessary for any of the reasons specified in the preceding proviso

${ }^{47}$ S.8 -Capacity of a female Hindu to take in adoption. - Any female Hindu-

(a) who is of sound mind,

(b) who is not a minor, and

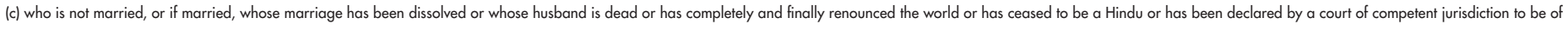
unsound mind, has the capacity to take a son or daughter in adoption

${ }^{48}$ S.9 - Persons capable of giving in adoption. -

(1) No person except the father or mother or the guardian of a child shall have the capacity to give the child in adoption.

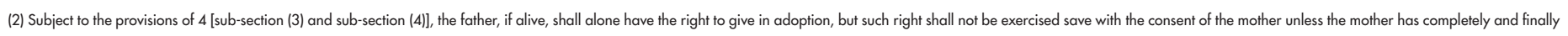
renounced the world or has ceased to be a Hindu or has been declared by a court of competent jurisdiction to be of unsound mind.

(3) The mother may give the child in adoption if the father is dead or has completely and finally renounced the world or has ceased to be a Hindu or has been declared by a court of competent jurisdiction to be of unsound mind

49 LNIND 1999 SC 165

50 S. 6 - Natural guardians of a Hindu Minor. The natural guardians of a Hindu minor, in respect of the minor's person as well as in respect of the minor's property (excluding his or her undivided interest in joint family property), are(a) in the case of a boy or an unmarried girl- the father. and after him, the mother: provided that the custody of a minor who has not completed the age of five years shall ordinarily be with the mother;

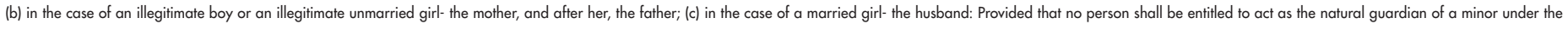


The legislation as well as judicial pronouncement indicates that the mother is second choice to be guardian of the child. The Court thus often tends to maintain the status quo as far as the position of women is concerned.

While Hindu women got the right of inheritance in $1956^{52}$, The coparcenary ${ }^{53}$ only admitted male members until $2005^{54}$. Under the Hindu Succession Act, 1956, while the woman's property ${ }^{55}$ ensuring it devolves on the heirs of the last male holder, in the absence of the woman's children, no such qualification is laid down in case of male succession. ${ }^{56}$ Premising that the law is based on divine precept has led to severe resistance to reform. ${ }^{57}$ Legislative reform would lead to certainty and uniformity. ${ }^{58}$ Muslim marriage (nikah) is defined to be a contract which has for its object the procreation and the legalizing of children ${ }^{59}$
A valid nikah must be performed in the presence of witnesses, the minimum requirement is, two male or one male and two females. ${ }^{60}$ This requirement of witnesses leads us to the supposition that a woman is so inferior that two women equal one man. Mention may be made that Islam permits polygamy. This premise is further strengthened by reference to the inheritance laws where in the share of a Muslim man is generally double than that of a woman. In Muslim law, there are mandatory heirs with fixed share as laid down in the Quran. For example, the share of a wife (in absence of children) is one fourth of the property ${ }^{61}$ of the husband, whereas the husband in a like situation gets half the property. However, the Shariat has definitely placed women in a better position as compared to the customary laws in ancient Arabia, which excluded women from inheritance. ${ }^{62}$

\section{provisions of this section-}

(a) if he has ceased to be a Hindu, or

(b) if he has completely and finally renounced the world by becoming a hermit (vanaprastha) or an ascetic (yati or sanyasi). Explanation. - In this section, the expressions" father" and" mother" do not include a step- father and a step- mother.

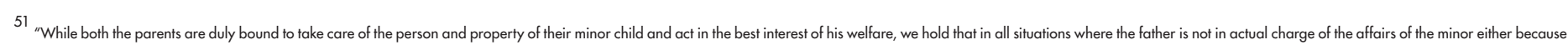

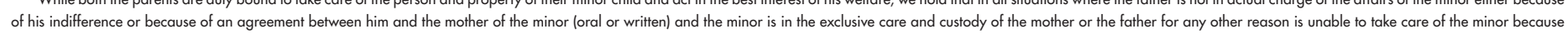

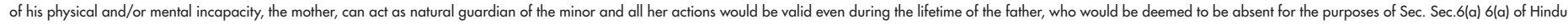
Minority and Guardianship Act and Sec. Sec 19(b) of Guardians and Wards Act."

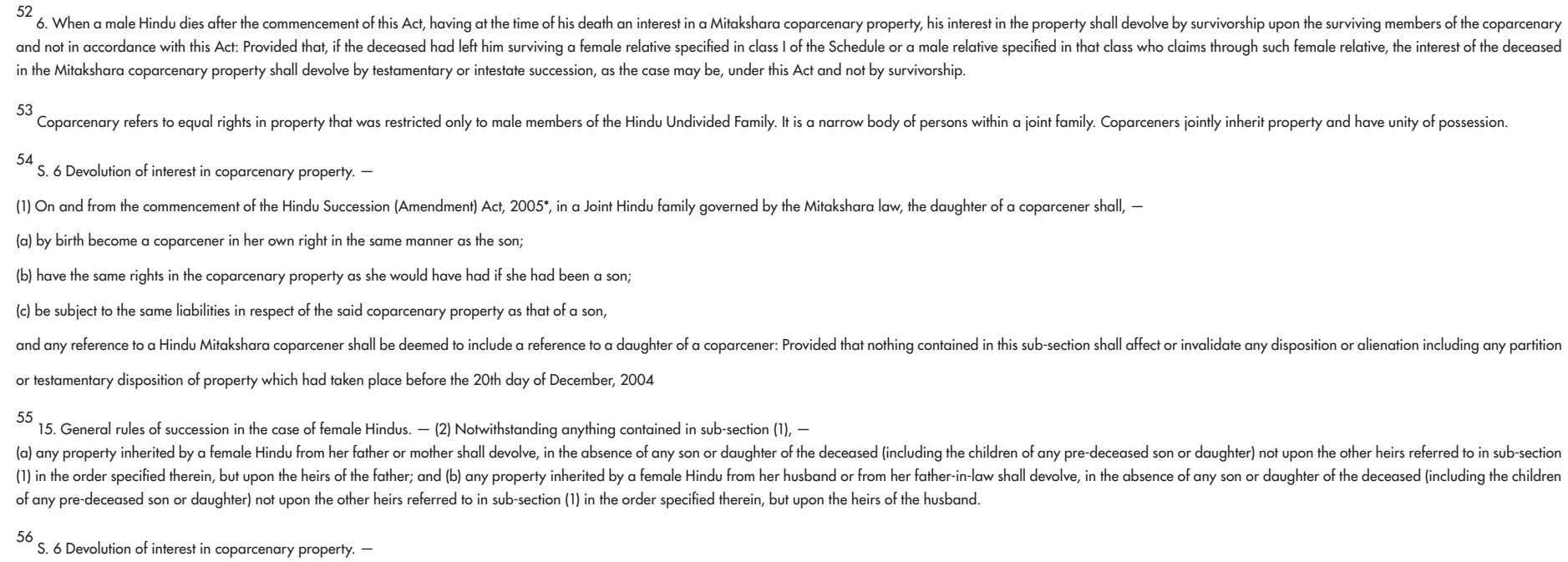


The laws also grant man a plethora of ways to divorce a woman ${ }^{63}$, but until the Dissolution of Muslim Marriages Act, $1939{ }^{64}$ intervened, women could divorce a man in a few ways, one of which was that he permitted her to divorce him. ${ }^{65}$ The Act granted to Muslim women rights in pari materia with other women. ${ }^{66}$ "Quoting in the judgment several Holy Quranic verses and from commentaries thereon by well-recognized scholars of great eminence, the learned Judge expressed disapproval of the statement that "the whimsical and capricious divorce by the husband is good in law, though bad in theology" and observed that such a statement is based on the concept that women were chattel belonging to men, which the Holy Quran does not brook." ${ }^{167}$ The triple talaq was abolished by Bangladesh before India. ${ }^{68}$
British governance was responsible for the enactment of laws governing native Christians. ${ }^{69}$ The Christians governed by Indian divorce Act which originally permitted a man to divorce a woman if she was guilty of adultery, whereas a woman had to prove adulty coupled with cruelty in order to obtain a divorce. The archaic legislation continued to be in force for decades. In Ammini E.J. v. Union of India ${ }^{70}$ the Kerala High Court observed:

"...While Section 10 confers on the husband a right to get divorce on proof of adultery simpliciter the wife is obliged to prove either cruelty or desertion along with adultery to get a divorce... The Indian Divorce Act, 1869 and the Christian Marriage Act, 1872 are dated survivals with an anti-woman slant..."

\footnotetext{
57 Mumtaz Ahmad, "The Muslim Family Laws Ordinance Of Pakistan." International Journal on World Peace 10, no. 3 (1993): 37-46. Accessed June 10, 2021. http://www.jstor.org/stable/20751912.

58 A. Suneetha, "Muslim Women and Marriage Laws: Debating the Model Nikahnama." Economic and Political Weekly 47, no. 43 (2012): 40-48. Accessed June 10, 2021. http://www.jstor.org/stable/41720299.

${ }^{59}$ Hedaya, p. 25

60 Ahmad A Mohammedan Law 26th Ed (2016) Central Law Agency

${ }^{61}$ ibid

62 Mohd Altaf Hussain Ahangar, "Succession Rights of Muslim Women in the Modern World: An Analytical Appraisal." Arab Law Quarterly 28, no. 2 (2014): 111-35. Accessed June 9, 2021. http://www.jstor.org/stable/43294660.

63 Talak, ila, zihar.

${ }^{64}$ No 8 of 1939

65 Talak-1-tafweez or delegated talak.

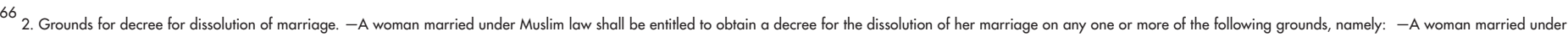
Muslim law shall be entitled to obtain a decree for the dissolution of her marriage on any one or more of the following grounds, namely $\backslash$ : "

(i) that the whereabouts of the husband have not been known for a period of four years; (i) that the whereabouts of the husband have not been known for a period of four years;"

(ii) that the husband has neglected or has failed to provide for her maintenance for a period of two years; (ii) that the husband has neglected or has failed to provide for her maintenance for a period of two years;"

(iii) that the husband has been sentenced to imprisonment for a period of seven years or upwards; (iii) that the husband has been sentenced to imprisonment for a period of seven years or upwards;"

(iv) that the husband has failed to perform, without reasonable cause, his marital obligations for a period of three years; (iv) that the husband has failed to perform, without reasonable cause, his marital obligations for a period of three years;"

(v) that the husband was impotent at the time of the marriage and continues to be so; (v) that the husband was impotent at the time of the marriage and continues to be so;"

(vi) that the husband has been insane for a period of two years or is suffering from leprosy or virulent venereal disease; (vi) that the husband has been insane for a period of two years or is suffering from leprosy or virulent venereal disease;"

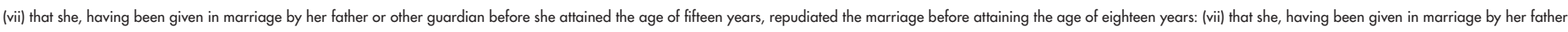

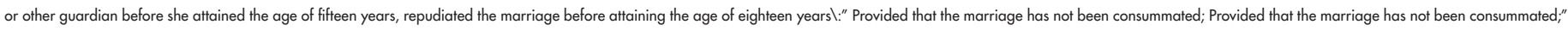
(viii) that the husband treats her with cruelty, that is to say, - (viii) that the husband treats her with cruelty, that is to say, -"

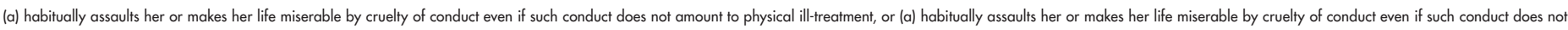
amount to physical ill-treatment, or"

(b) associates with women of evil repute or leads an infamous life, or (b) associates with women of evil repute or leads an infamous life, or"

(c) attempts to force her to lead an immoral life, or (c) attempts to force her to lead an immoral life, or"

(d) disposes of her property or prevents her exercising her legal rights over it, or (d) disposes of her property or prevents her exercising her legal rights over it, or"
} 
However, the change was brought about only in 2001. ${ }^{71}$ The Indian Succession Act as applicable to Christians discriminates between the parents of the propositus, the father excludes the mother, and siblings, whereas the mother inherits in the absence of the father and simultaneously with the brothers and sisters. ${ }^{72}$

The Civil Code of Goa, is a Portuguese inherited legislation ${ }^{73}$ applicable to all Goans. Unlike the rest of India, all Goans irrespective of religion are governed by this code which applies 'uniformly'. Under the Code, marriage is defined as a perpetual contract made between two persons of different sex with the purpose of legitimately constituting a family. ${ }^{74}$ The regime of community of property applies by default if no other is specified ${ }^{75}$. Goa claims to have a uniform civil code, ${ }^{76}$ while it is true that the Code treats the religions without bias, by applying to all goans irrespective of religion, it is patently male centric. The law insidiously promotes inequality between the spouses, for example, vide, the incapacity of married women in property matters ${ }^{77}$ The wife may not except in cases which are specially authorized by law, acquire or dispose of assets or contract obligations, without the husband's permission. ${ }^{78}$ However in the exceptional cases when the husband permits or is declared incompetent by court, the wife is the administrator of the couple's assets. It may be noted that this incapacity does not apply to household management. ${ }^{79}$

e) obstructs her in the observance of her religious profession or practice, or (e) obstructs her in the observance of her religious profession or practice, or"

$(f)$ if he has more wives than one, does not treat her equitably in accordance with the injunctions of the Quran; (f) if he has more wives than one, does not treat her equitably in accordance with the injunctions of the Quran;"

(ix) on any other ground which is recognized as valid for the dissolution of marriages under Muslim law: (ix) on any other ground which is recognized as valid for the dissolution of marriages under Muslim law l:" Provided that-

(a) no decree shall be passed on ground (iii) until the sentence has become final; (a) no decree shall be passed on ground (iii) until the sentence has become final;"

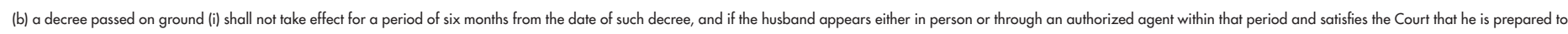

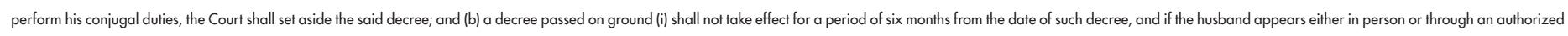
agent within that period and satisfies the Court that he is prepared to perform his conjugal duties, the Court shall set aside the said decree; and"

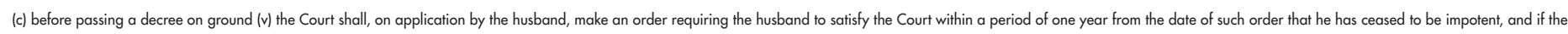

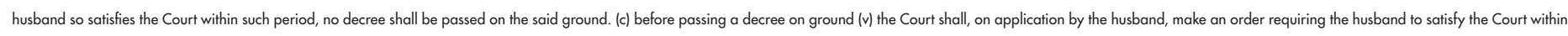
a period of one year from the date of such order that he has ceased to be impotent, and if the husband so satisfies the Court within such period, no decree shall be passed on the said ground."

${ }^{67}$ Shayara Bano v Union of India (2017) 9 SCC 1

${ }^{68}$ Anees Ahmed. "Reforming Muslim Personal Law." Economic and Political Weekly 36, no. 8 (2001): 618-19. Accessed June 9, 2021. http://www.jstor.org/stable/4410313.

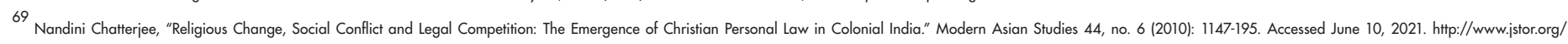
stable/40926527.

${ }^{70}$ AIR 1995 Ker 252

7110 Grounds for dissolution of marriage. -

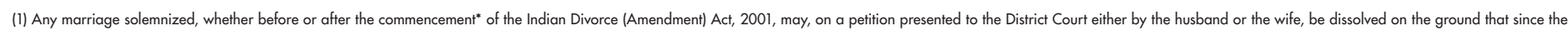
solemnization of the marriage, the respondent-

(i) has committed adultery; or

(ii) has ceased to be Christian by conversion to another religion; or

(iii) has been incurably of unsound mind for a continuous period of not less than two years immediately preceding the presentation of the petition; or

(iv) has, for a period of not less than two years immediately preceding the presentation of the petition, been suffering from a virulent and incurable form of leprosy; or

(v) has, for a period of not less than two years immediately preceding the presentation of the petition, been suffering from venereal disease in a communicable form; or

(vi) has not been heard of as being alive for a period of seven years or more by those persons who would naturally have heard of the respondent if the respondent had been alive; or

(vii) has willfully refused to consummate the marriage and the marriage has not therefore been consummated; or

(viii) has failed to comply with a decree for restitution of conjugal rights for a period of two years or upwards after the passing of the decree against the respondent; or

(ix) has deserted the petitioner for at least two years immediately preceding the presentation of the petition; or

(x) has treated the petitioner with such cruelty as to cause a reasonable apprehension in the mind of the petitioner that it would be harmful or injurious for the petitioner to live with the respondent.

(2) A wife may also present a petition for the dissolution of her marriage on the ground that the husband has, since the solemnization of the marriage, been guilty of rape, sodomy or bestiality.] 
However, the change was brought about only in 2001. ${ }^{71}$ The Indian Succession Act as applicable to Christians discriminates between the parents of the propositus, the father excludes the mother, and siblings, whereas the mother inherits in the absence of the father and simultaneously with the brothers and sisters. ${ }^{72}$

The Civil Code of Goa, is a Portuguese inherited legislation ${ }^{73}$ applicable to all Goans. Unlike the rest of India, all Goans irrespective of religion are governed by this code which applies 'uniformly'. Under the Code, marriage is defined as a perpetual contract made between two persons of different sex with the purpose of legitimately constituting a family. ${ }^{74}$ The regime of community of property applies by default if no other is specified ${ }^{75}$. Goa claims to have a uniform civil code, ${ }^{76}$ while it is true that the Code treats the religions without bias, by applying to all goans irrespective of religion, it is patently male centric. The law insidiously promotes inequality between the spouses, for example, vide, the incapacity of married women in property matters ${ }^{77}$ The wife may not except in cases which are specially authorized by law, acquire or dispose of assets or contract obligations, without the husband's permission. ${ }^{78}$ However in the exceptional cases when the husband permits or is declared incompetent by court, the wife is the administrator of the couple's assets. It may be noted that this incapacity does not apply to household management. ${ }^{79}$ The wife has other disabilities too, she is incapable of accepting conditional or onerous gifts without husband's permission. ${ }^{80}$

All the various personal laws have one thing in common, they favour the male over the female. ${ }^{81}$ Women's issues and rights are always on the backburner of the political agenda. ${ }^{82}$ The discrepancies between the various personal laws operates as a veritable "conflict of laws." 83

\footnotetext{
${ }^{72} \mathrm{~S} .42$. Where intestate's father living. - If the intestate's father is living, he shall succeed to the property.

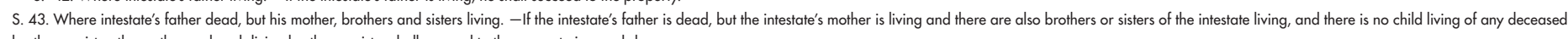
brother or sister, the mother and each living brother or sister shall succeed to the property in equal shares.

73 Goa, Daman and Diu (Administration) Act, 1962

74 Art 1056

${ }^{75}$ Art 1098

${ }^{76}$ Civil code of 1867

77 Art 1193.

78 Art 1116.

${ }^{79}$ Art 39 of decree no 1

${ }^{80}$ Art 1478

${ }^{81}$ Archana Parashar, "Gender Inequality and Religious Personal Laws in India." The Brown Journal of World Affairs 14, no. 2 (2008): 103-12. Accessed June 9, 2021. http://www.jstor.org/stable/24590717.

82 "Reversing the Option: Civil Codes and Personal Laws." Economic and Political Weekly 31, no. 20 (1996): 1180-183. Accessed June 9, 2021. http://www.jstor.org/stable/4404139.

83 T. S. Rama Rao, "Conflict Of Laws In India." Zeitschrift Für Ausländisches Und Internationales Privatrecht 23, no. 2 (1958): 259-79. Accessed June 9, 2021. http://www.jstor.org/stable/27873899.

${ }^{84}$ Akolda M. Tier, "Conflict of Laws and Legal Pluralism in the Sudan." The International and Comparative Law Quarterly 39, no. 3 (1990): 611-40. Accessed June 10, 2021. http://www.jstor.org/stable/760119.

85 D. C. Manooja, "UNIFORM CIVIL CODE: A SUGGESTION." Journal of the Indian Law Institute 42, no. 2/4 (2000): 448-57. Accessed June 10, 2021. http://www.jstor.org/stable/43953824.

${ }^{86}$ Art 44. Uniform civil code for the citizens The State shall endeavor to secure for the citizens a uniform civil code throughout the territory of India

${ }^{87}$ Sarla Mudgal v. Union of India AIR 1995 SC 1531
} 


\section{Chimera of Uniform Civil Code}

A plurality of laws governing essentially similar matters not only leads to injustice but also weakens the unity of the Country ${ }^{84}$ The Government claims that the hindrance to enacting a uniform law, is the resistance inherent in the target subject. ${ }^{85}$ The enactment of a Uniform Civil Code has been eluding India from 1950 till date. The Constitution requires it of the State, ${ }^{86}$ Till the time we achieve the goal - uniform civil code for all the citizens of India - there is an open inducement to a Hindu

\section{Conclusion}

The legislature is unwilling to legislate, the judiciary is unable to do so, and the Country seems content with mere judicial platitudes rather than concrete action in its quest for a truly uniform civil code which would not discriminate on grounds of religion or gender. ${ }^{89}$

"In At first blush, it may appear as if it is a beneficial legislation intended to serve the interests of women but, on closer examination, it would be found that the provision contained in husband, who wants to enter into second marriage while the first marriage is subsisting, to become a Muslim. Since monogamy is the law for Hindus and the Muslim law permits as many as four wives in India, errand Hindu husband embraces Islam to circumvent the provisions of the Hindu law and to escape from penal consequences. ${ }^{87}$

But right from Shah Bano to Shayara Bano, it appears that the Country has settled for mere platitudes. ${ }^{88}$ the section is a kind of - romantic paternalism I which stems from the assumption that women, like chattels, are the property of men." 90 These words of the Supreme Court could be used to describe most of the personal laws in India.

Misogyny like any other extremist theory is based on prejudice or bias, which should not factor in the narrative of a modern, egalitarian society. ${ }^{91}$

As far in 1860 when the I.P.C. was enacted Lord Macaulay

${ }^{88}$ Chief Justice Y.V. Chandrachud in Mohd. Ahmed Khan v. Shah Bano Begum held as under

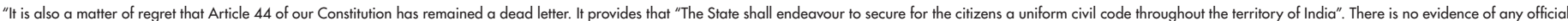

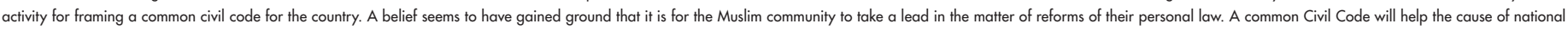
integration by removing disparate loyalties to laws which have conflicting ideologies."

In Ms. Jordan Diengdeh v. S.S. Chopra Chinnappa Reddy, J. speaking for the Court referred to the observations of Chandrachud, CJ in Shah Bano Begum's case and observed as under:

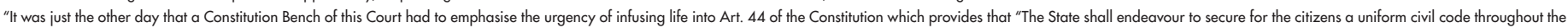

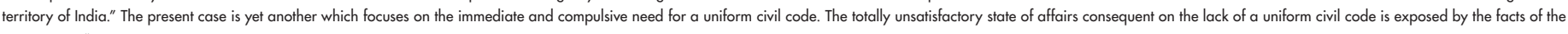
present case."

89

Shabbeer Ahmed, and Shabeer Ahmed. "Uniform Civil Code (Article 44 Of The Constitution) A Dead Letter." The Indian Journal of Political Science 67, no. 3 (2006): 545-52. Accessed June 9, 2021. hitp://www.jstor.org/stable/41856241. 
moved on the premise women had no rights independent of their husbands, and were treated as chattel or property. Hence, the offence of adultery was treated as an injury to the husband, since it was considered to be a theft of his property, for which he could proceed to prosecute the offender.

Till date legislation and precedent generally move on the premise that woman is some sort of inferior being, inferior in intellect and stamina, whose main purpose in life is child bearing ${ }^{92}$ or being subsidiary to man. This role of woman has been glorified in scripture and folk lore. Reference may be made to Savitri rescuing Satyavan from death, to the adage that states "behind every successful man, there is a woman", to Pandora's Box.

It is high time we followed the CEDAW in letter and spirit, and become "aware that a change in the traditional role of men as well as the role of women in society and in the family is needed to achieve full equality between men and women," which will result in a strong nation and a strong world.

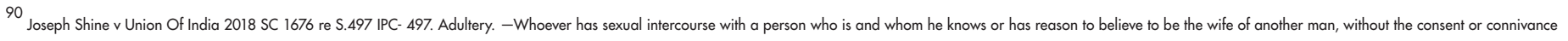

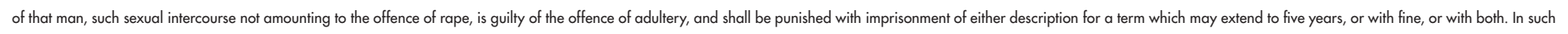
case the wife shall not be punishable as an abettor.

${ }^{91}$ Tracy Hayes, "'As A Man Is Rarely Adored By Another': Misogyny And The Homosocial In A Pair Of Blue Eyes." The Hardy Society Journal 15, no. 2 (2019): 43-48. Accessed June 9, 2021. hittps://www.jstor.org/stable/48563538.

92 Aware that the role of women in procreation should not be a basis for discrimination but that the upbringing of children requires a sharing of responsibility between men and women and society as a whole, (CEDAW)
} 
ULPLR I ULP LAW REVIEW I REVISTA DE DIREITO DA ULP

VOL.15 I №1

DOI: $10.46294 /$ ulplr - rdulp.v15i1.7942

\section{References}

"Reversing the Option: Civil Codes and Personal Laws." Economic and Political Weekly 31, no. 20 (1996): 1180-183. Accessed June 9, 2021. http://www.jstor.org/stable/4404139.

AHANGAR, MOHD ALTAF HUSSAIN. "Succession Rights of Muslim Women in the Modern World: An Analytical Appraisal." Arab Law Quarterly 28, no. 2 (2014): 111-35. Accessed June 9, 2021. http://www.jstor.org/stable/43294660.

AHMAD A MOHAMMEDAN Law 26th Ed (2016) Central Law Agency

AHMAD, MUMTAZ. "The Muslim Family Laws Ordinance Of Pakistan." International Journal on World Peace 10, no. 3 (1993): 37-46. Accessed June 10, 2021. http://www.jstor.org/stable/20751912.

AHMED, SHABBEER, AND SHABEER AHMED. "Uniform Civil Code (Article 44 Of The Constitution) A Dead Letter." The Indian Journal of Political Science 67, no. 3 (2006): 545-52. Accessed June 9, 2021. http://www.jstor.org/stable/41856241.

AMRITA SHODHAN. "Women, Personal Laws and the Changing Juridical Practice." Economic and Political Weekly 35, no. 15 (2000): 1259-261. Accessed June 10, 2021. http://www.jstor.org/stable/4409145.

ANEES AHMED. "Reforming Muslim Personal Law." Economic and Political Weekly 36, no. 8 (2001): 618-19. Accessed June 9, 2021. http://www.jstor.org/stable/4410313.

BARKER, KIM, AND OLGA JURASZ. "Online Misogyny: A Challenge For Digital Feminism?" Journal of International Affairs 72, no. 2 (2019): 95-114. Accessed June 9, 2021. https://www.jstor.org/stable/26760834.

BERER, MARGE. "Abortion Law and Policy Around the World: In Search of Decriminalization." Health and Human Rights 19, no. 1 (2017): 13-27. Accessed June 9, 2021. http://www.jstor.org/stable/90007912.

Bible NIV: Genesis 1

BUITEN, DENISE. "Silences Stifling Transformation: Misogyny and Gender-Based Violence in the Media." Agenda: Empowering Women for Gender Equity, no. 71 (2007): 114-21. Accessed June 9, 2021. http://www.jstor.org/stable/27739254.

Cambridge Dictionary https://dictionary.cambridge.org/dictionary/english/misogyny (March 3, 2021)

CAMERON, DEBORAH. "Feminist Linguistic Theories." In Contemporary Feminist Theories, edited by Jackson Stevi and Jones Jackie, 147-61. Edinburgh: Edinburgh University Press, 1998. Accessed June 9, 2021. http://www.jstor.org/stable/10.3366/i. ctvxcrxc7.13.

CHAPMAN, JEAN. "Violence against Women in Democratic India: Let's Talk Misogyny." Social Scientist 42, no. 9/10 (2014): 49-61. Accessed June 9, 2021. http://www.jstor.org/stable/24372976.

Charter of the United Nations, 1945

CHATTERJEE, NANDINI. "Religious Change, Social Conflict and Legal Competition: The Emergence of Christian Personal Law in Colonial India." Modern Asian Studies 44, no. 6 (2010): 1147-195. Accessed June 10, 2021. http://www.jstor.org/ stable/40926527. 
ULPLR I ULP LAW REVIEW I REVISTA DE DIREITO DA ULP

VOL.15 I №1

DOI: $10.46294 /$ ulplr - rdulp.v15i1.7942

Civil code of 1867

Das, Subhamoy. "Famous Female Figures of Vedic India." Learn Religions, Feb. 11, 2020, learnreligions.com/famous-femalefigures-of-vedic-india-1770399 (March 3, 2021)

DHAVAN, RAJEEV. "Religious Freedom in India." The American Journal of Comparative Law 35, no. 1 (1987): 209-54. Accessed June 10, 2021. doi:10.2307/840167.

DÍAZ, PABLO CASTILLO, AND NAHLA VALII. "Symbiosis Of Misogyny And Violent Extremism: New Understandings And Policy Implications." Journal of International Affairs 72, no. 2 (2019): 37-56. Accessed June 9, 2021. https://www.jstor.org/ stable/26760831.

GOA, DAMAN AND DIU (Administration) Act, 1962

HAYES, TRACY. "'As A Man Is Rarely Adored By Another': Misogyny And The Homosocial In A Pair Of Blue Eyes." The Hardy Society Journal 15, no. 2 (2019): 43-48. Accessed June 9, 2021. https://www.jstor.org/stable/48563538.

HERRING, JONATHAN. "The Severity Of Domestic Abuse." National Law School of India Review 30, no. 1 (2018): $37-50$. Accessed June 9, 2021. https://www.jstor.org/stable/26743931.

Hindu Succession (Amendment) Act, 2005

Holland J Misogyny the World's Oldest Prejudice 2006 Robinson London

HUMM, MAGGIE. "Feminist Literary Theory." In Contemporary Feminist Theories, edited by Jackson Stevi and Jones Jackie, 194212. Edinburgh: Edinburgh University Press, 1998. Accessed June 9, 2021. http://www.jstor.org/stable/10.3366/i.ctvxcrxc7.16. HUYCK, JEFFERDS. "Another Sort Of Misogyny: Aeneid 9.141-142." Harvard Studies in Classical Philology 108 (2015): 245-63. Accessed June 9, 2021. http://www.jstor.org/stable/44157815.

In Raghubans Saudagar Singh v. The State of Punjab AIR 1972 P \& H 117

Indian Divorce (Amendment) Act, 2001

International Covenant on Economic, Social and Cultural Rights, 1966

DUNCAN M. DERRETT. "Statutory Amendments of the Personal Law of Hindus Since Indian Independence." The American Journal of Comparative Law 7, no. 3 (1958): 380-93. Accessed June 10, 2021. doi:10.2307/837671.

JOSEPH SHINE v Union Of India 2018 SC 1676

KATHRYN HARRISON Joan of Arc: A Life Transfigured Reprint edition (2015) Anchor

MANOOJA, D. C. "UNIFORM CIVIL CODE: A SUGGESTION." Journal of the Indian Law Institute 42, no. 2/4 (2000): $448-57$. Accessed June 10, 2021. http://www.jstor.org/stable/43953824.

MAYNARD, MARY. "Women's Studies." In Contemporary Feminist Theories, edited by Jackson Stevi and Jones Jackie, $247-58$. Edinburgh: Edinburgh University Press, 1998. Accessed June 9, 2021. http://www.jstor.org/stable/10.3366/i.ctvxcrxc7.19.

MERCER, CHRISTIA. "The Philosophical Roots of Western Misogyny." Philosophical Topics 46, no. 2 (2018): 183-208. Accessed June 9, 2021. https://www.jstor.org/stable/26927955.

Merriam Webster Dictionary merriam-webster.com/dictionary/androcentric (March 3, 2021) 
ULPLR I ULP LAW REVIEW I REVISTA DE DIREITO DA ULP

VOL.15 I №1

DOI: $10.46294 /$ ulplr - rdulp.v15i1.7942

MÖLLER, LENA-MARIA. "An Enduring Relic: Family Law Reform and the Inflexibility of Wil『ya." The American Journal of Comparative Law 63, no. 4 (2015): 893-925. Accessed June 9, 2021. https://www.jstor.org/stable/26425444.

NAGLE, ANGELA. "The New Man of 4chan." The Baffler, no. 30 (2016): 64-76. Accessed June 9, 2021. http://www.jstor.org/ stable/43959201.

Navtej Singh Johar v Union of India AIR 2018 SC 4321

PARASHAR, ARCHANA. "Gender Inequality and Religious Personal Laws in India." The Brown Journal of World Affairs 14, no. 2 (2008): 103-12. Accessed June 9, 2021. http://www.jstor.org/stable/24590717.

PHILIPS, AMALI. "Sharia and Shah Bano: Multiculturalism and Women's Rights." Anthropologica 53, no. 2 (2011): $275-90$. Accessed June 10, 2021. http://www.jstor.org/stable/41473879.

RAO, T. S. RAMA. "Conflict Of Laws In India." Zeitschrift Für Ausländisches Und Internationales Privatrecht 23, no. 2 (1958): 25979. Accessed June 9, 2021. http://www.jstor.org/stable/27873899.

RATTAN, JYOTI. "Uniform Civil Code In India: A Binding Obligation Under International And Domestic Law." Journal of the Indian Law Institute 46, no. 4 (2004): 577-87. Accessed June 10, 2021. http://www.jstor.org/stable/43951938.

RIEDER, PAULA M. "The Uses and Misuses of Misogyny: A Critical Historiography of the Language of Medieval Women's Oppression." Historical Reflections / Réflexions Historiques 38, no. 1 (2012): 1-18. Accessed June 9, 2021. http://www.jstor.org/ stable/23267757.

RUETHER, ROSEMARY RADFORD. "Sexism and Misogyny in the Christian Tradition: Liberating Alternatives." Buddhist-Christian Studies 34 (2014): 83-94. Accessed June 9, 2021. http://www.jstor.org/stable/24801355.

SARLA MUDGAL V. Union of India AIR 1995 SC 1531

SCOULAR, JANE. "Feminist Jurisprudence." In Contemporary Feminist Theories, edited by Jackson Stevi and Jones Jackie, $62-72$. Edinburgh: Edinburgh University Press, 1998. Accessed June 9, 2021. http://www.jstor.org/stable/10.3366/j.ctvxcrxc7.7. SHAYARA BANO v Union of India (2017) 9 SCC 1

SREYASHI GHOSH "Intersectional Feminism - Desi Style" Saturday, May 2, 2020 https://feminisminindia.com/2018/01/11/ manusmriti-ultimate-guide-good-woman/ (March 3, 2021)

SUBRAMANIAN, NARENDRA. "Legal Change and Gender Inequality: Changes in Muslim Family Law in India." Law \& Social Inquiry 33, no. 3 (2008): 631-72. Accessed June 10, 2021. http://www.jstor.org/stable/20108777.

SUNEETHA, A. "Muslim Women and Marriage Laws: Debating the Model Nikahnama." Economic and Political Weekly 47, no. 43 (2012): 40-48. Accessed June 10, 2021. http://www.jstor.org/stable/41720299.

TARKUNDE, V.M. "Secularism and the Indian Constitution." India International Centre Quarterly 22, no. 1 (1995): 143-52. Accessed June 10, 2021. http://www.jstor.org/stable/23003717.

The Constitution of India, 1950

The Convention on the Elimination of All Forms of Discrimination against Women, 1979

The Divorce Act, 1869 
The Hindu Adoptions and Maintenance Act, 1956

The Hindu Minority and Guardianship Act, 1956

The Hindu Succession Act, 1956

The Indian Succession Act, 1925

The Universal Declaration of Human Rights, 1948

The Indian Penal Code, 1860

TIER, AKOLDA M. "Conflict of Laws and Legal Pluralism in the Sudan." The International and Comparative Law Quarterly 39, no. 3 (1990): 611-40. Accessed June 10, 2021. http://www.jstor.org/stable/760119. 